\title{
Evaluation of postharvest properties in different passion fruit species during ripening
}

\section{Evaluación de propiedades poscosecha de diferentes especies de fruta de la pasión durante la maduración}

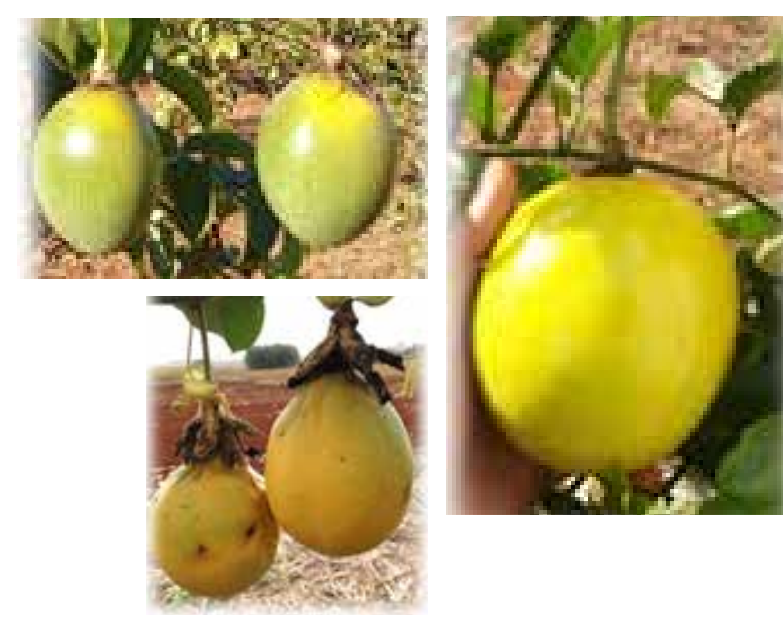

FRANCIELLY RODRIGUES GOMES ${ }^{1,3}$

MOAB ACACIO BARBOSA'

CLÁUDIA DAYANE MARQUES RODRIGUES'

ALEJANDRO HURTADO-SALAZAR ${ }^{2}$

AMÉRICO NUNES DA SILVEIRA-NETO'

HILDEU FERREIRA DA ASSUNÇÃO' ${ }^{1}$

DANIELLE FABÍOLA PEREIRA DA SILVA'

Fruits from a yellow passion fruit genotype (left), the commercial cultivar of yellow passion fruit 'FB 200' (right), and a sweet passion fruit genotype (down).

Photos: F.R. Gomes

\begin{abstract}
During ripening, many transformations occur in passion fruits. The ripening stage affects fruit quality and post-harvest properties. Fruits with $65 \%$ yellow epidermis present chemical characteristics that meet industrial standards, facilitating harvest estimations and loss avoidance. Thus, this study aimed to evaluate the post-harvest properties of passion fruit species (genotypes of the yellow passion fruit and sweet passion fruit, and yellow passion fruit cultivar FB 200) during ripening. The fruits were evaluated by the color of the epidermis and the chemical characteristics of the pulp (titratable acidity, vitamin C, carotenoids, soluble solids content, and ratio). This experiment was conducted with a completely randomized design and a split-plot arrangement, where the plots were the species and the subplots were the evaluation periods $(50,58,66,74$ and 82 days after anthesis), with four replications and 10 fruits per plot. The yellow passion fruit genotype and cultivar, harvested at 82 days after anthesis, presented desirable characteristics for the juice industry and for fresh consumption. The sweet passion fruit had a higher soluble solids content and titratable acidity ratio because of its high content of soluble solids and low acidity, which translate to a better fruit flavor.
\end{abstract}

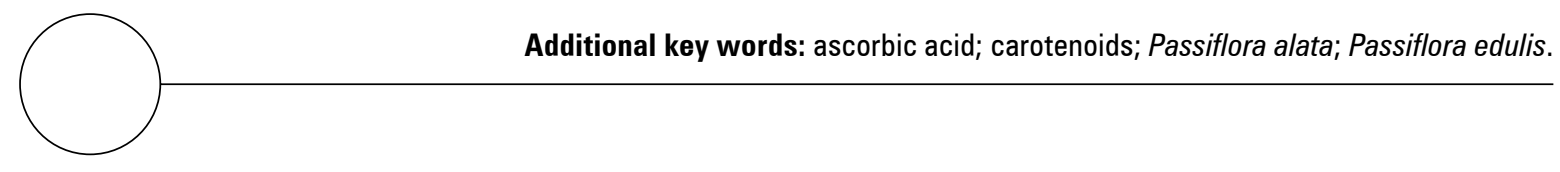

\footnotetext{
1 Universidade Federal de Jataí, Jataí (Brazil), ORCID Gomes, F.R.: 0000-0001-7282-0719; ORCID Barbosa, M.A.: 0000-0001-6937-5642; ORCID Rodrigues, C.D.M.: 0000-0002-8502-6810; ORCID Silveira-Neto, A.N.: 0000-0001-5997-4684; ORCID Assunção, H.F.: 0000-0002-4203-6568; ORCID Silva, D.F.P.: 0000-0001-7366-5650

2 Universidad de Caldas, Manizales (Colombia). ORCID Hurtado-Salazar, A.: 0000-0002-1251-125X

3 Corresponding author. fram_rodgomes@hotmail.com
} 


\section{RESUMEN}

Durante la maduración del maracuyá, se producen muchas transformaciones. La etapa de maduración afecta a la calidad de la fruta y a las propiedades poscosecha. Se sabe que los frutos con un $65 \%$ de epidermis amarilla presentan características químicas dentro del estándar requerido por la industria, lo que permite anticipar la cosecha y evitar pérdidas. Así, este trabajo tuvo como objetivo evaluar las propiedades postcosecha de especies de fruta de la pasión (amarilla, dulce y el cv. FB 200) durante la maduración. Los frutos fueron evaluados por el color de la epidermis y las características químicas de la pulpa (acidez titulable, vitamina C, carotenoides, sólidos solubles y proporción). El experimento se realizó en un diseño completamente al azar con un arreglo de parcelas subdivididas, donde las parcelas constituyen las especies y las subparcelas constituyen los períodos de evaluación (50, 58, 66, 74 y 82 días después de la antesis), con cuatro repeticiones y 10 frutos por parcela. Los frutos del genotipo de maracuyá amarilla y el cultivar cosechados 82 días después de la antesis presentan características deseables ya sea para la industria del jugo o para consumo fresco. La fruta de la pasión dulce presenta una mayor proporción entre sólidos solubles y acidez titulable, debido a su alto contenido en sólidos solubles y bajo contenido de acidez, lo que implica un gran sabor a fruta.

Palabras clave adicionales: ácido ascórbico; carotenoides; Passiflora alata; Passiflora edulis.

Received: 21-10-2020 Accepted: 07-12-2020 Published: 08-01-2021

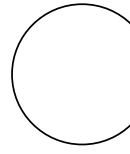

The passion fruit belongs to the Passifloraceae Family and is grown in tropical and subtropical climate countries. The larger producers are located in South America, where Brazil, Colombia, Peru and Ecuador stand out (Coelho et al., 2016). Brazil is the world's biggest producer of passion fruit with about 700,000 $t$ of fruits per year, while Colombia produced about $228,000 \mathrm{t}$ in a cultivated area of 10,000 ha in 2018. However, increasing productivity requires fruits that meet the standards required by markets for fresh consumption and industrial processing, i.e. big fruits with good peel appearance and color, a good ratio of soluble solids and titratable acidity and a good juice yield (Aires et al., 2020; Hurtado-Salazar et al., 2020; Martínez et al., 2020; Medeiros et al., 2020).

Commercial fruit production for the genus Passiflora is restricted to the species Passiflora edulis f. edulis Sims (yellow passion fruit) because of its high fruit quality and juice yield, which are connected to its economic potential and quick financial return (Braga et al., 2017; Ribeiro et al., 2019). However, the species Passiflora alata Curtis (sweet passion fruit) has great importance in the production of herbal medicines (Nascimento and Barbosa, 2014) and is highly regarded because of its taste and pleasant smell, which translate to higher market values (Alves et al., 2012).

\section{INTRODUCTION}

During ripening, carotenoids and other phenolic compounds are degraded by biochemical reactions that generate other volatile compounds, in addition, chemical transformations occur, such as sugar accumulation and reduction of acidity, with changes in peel color (Coelho et al., 2010; Rotili et al., 2018).

There are reports that, at the end of ripening, the sweet passion fruit pulp (Passiflora alata Curtis) presents about $18^{\circ} \mathrm{Brix}$, with titratable acidity ranging from 1 to 2\% citric acid (Alves et al., 2012); the yellow passion fruit (Passiflora edulis Sims) presents about $16^{\circ}$ Brix, with $4 \%$ citric acid (Vianna-Silva et al., 2008); the orange cv. Valência fruit (Citrus sinensis (L.) Osbeck) when produced in the conventional system presents about $11^{\circ} \mathrm{Brix}$, with titratable acidity ranging from 0.8 to $1.0 \%$ citric acid (Arruda et al., 2011); and the mango 'Ubá' (Mangifera indica) presents pulp with about $18^{\circ}$ Brix and $0.5 \%$ citric acid (Benevideset al., 2008).

The ripening stage directly influences fruit quality and post-harvest shelf-life. Fruit harvest occurs after natural abscission and can lead to significant losses. Therefore, changes caused by ripening, especially color changes, aid harvest plans (Botelho et al., 2019). Fruits with approximately 65\% yellow colored epidermis have chemical characteristics in the pulp that 
meet the required standards, aiding harvest plans and reducing risks of wrinkles, wilting, and deterioration (Silva et al., 2005).

An ideal harvest point provides fruits with better quality and reduces losses. Therefore, this study aimed to evaluate the post-harvest properties in a yellow passion fruit genotype (P. edulis Sims), a sweet passion fruit genotype (P. alata), and the yellow passion fruit cultivar FB 200 (Flora Brasil 200 - P. edulis $\mathrm{f}$. flavicarpa) at different ripening stages.

\section{MATERIALS AND METHODS}

This experiment was conducted in an orchard located at the Federal University of Jataí, in Goias state - Brazil, where the annual average temperature is $23.3^{\circ} \mathrm{C}$, and the annual rainfall index is $1,541 \mathrm{~mm}$ (Melo and Dias, 2019). The orchard had espaliers spaced at $3 \times 4$ $\mathrm{m}$ with two-wire threads, irrigated daily with a dripping system (Gomes et al., 2019).

A completely randomized design in a split-plot scheme was adopted, with the fruits (yellow passion fruit, sweet passion fruit, and yellow passion fruit cultivar FB 200) as the plots, and the days of evaluation as the subplots, with four replicates and 10 fruits per plot.

Fruits in the full physiological stage were harvested manually, based on the color change from green to yellow, when harvested fruits had an epidermis that was at least $20 \%$ yellow. The harvests were performed at five points: 50, 58, 66, 74 and 82 days after anthesis (DAA) because the literature indicates that fruits are physiologically mature at 50 DAA.

At each evaluation period, 40 fruits from each species were harvested: a yellow passion fruit genotype (Passiflora edulis Sims), a sweet passion fruit genotype (Passiflora alata), and yellow passion fruit commercial cultivar 'FB 200' (Passiflora edulis f. flavicarpa). After harvest, the fruits were sent to the laboratory in plastic boxes with one fruit layer, where they were washed in running water, dried at room temperature, and evaluated for epidermis color, titratable acidity, vitamin $\mathrm{C}$ content, carotenoids, soluble solids and ratio between the soluble solids and titratable acidity content.

The epidermis color was evaluated with the CIElab model using a colorimeter that measures the reflected light with a cartesian coordinate system (Konica Minolta, model CR-10), in which units or points of approximate visual uniformity were obtained (Kong et al., 2019). Two readings on opposite sides of the epidermis on each fruit were taken to obtain the Hue angle $\left(h^{\circ}\right)$, which represents the color of the samples.

The soluble solids content (SSC) was determined as recommended by AOAC (2016) method number 932.12, in which some drops of the juice samples were placed in a portable refractometer (Atago model Pal-1), and, after the reading, the results were expressed in ${ }^{\circ}$ Brix.

The titratable acidity (TA) was evaluated following the procedure proposed by AOAC method number 942.15 (AOAC, 2016), with titration of $5 \mathrm{~mL}$ of pulp in a $0.1 \mathrm{~N} \mathrm{NaOH}$ solution and phenolphthalein, in which the solution was stirred until the samples presented a persistent pink color. The results were given in $\%$ of citric acid/100 $\mathrm{mL}$ of pulp.

The ratio, which represents the flavor of the fruits, was obtained through the relationship between the soluble solids content and titratable acidity (SSC/ TA).

The vitamin $\mathrm{C}$ content was determined by titration with Tillmanns reagent, using 2,6-dichloroindophenol sodium salt, following the procedure indicated by AOAC (2016) method number 967.21. The results were given in $\mathrm{mg}$ of ascorbic acid/100 $\mathrm{mL}$ of pulp.

For the carotenoid content, $1.5 \mathrm{~mL}$ of pure acetone were added to $150 \mathrm{mg}$ of pulp, stirred for $24 \mathrm{~h}$ at a low temperature and in absence of light, followed by analysis with a spectrophotometer, in which the absorbances were determined at 470, 646.8 and 663.2 $\mathrm{nm}$, and the carotenoid levels were determined with the equations described by Lichtenthaler (1987), expressed as $\mu \mathrm{g}$ per $\mathrm{mL}$ of extract.

The data were submitted to analysis of variance. Regression models physiologically explained the behavior of the fruits; these models were based on the coefficient of determination and the potential to explain the biological phenomenon. The averages of the analyzed characteristics were compared with the Tukey test $(P<0.05)$. The data were analyzed with SAS (SAS, 2004).

\section{RESULTS AND DISCUSSION}

The titratable acidity of the fruits presented a linear behavior, increasing over time and reaching the highest point at $82 \mathrm{DAA}$, especially for the FB 200 cultivar 
and the yellow passion fruit genotype. The cultivar had the greatest citric acid accumulation at the end of the experiment. The sweet passion fruit presented a lower acidity content during ripening, probably because its main characteristic is sweeter pulp (Pereira et al., 2018). The estimated citric acid percentage for each $100 \mathrm{~mL}$ of pulp for the FB 200 cultivar was 2.91\% at $50 \mathrm{~d}$ and $6.04 \%$ at $82 \mathrm{~d}$; for the yellow passion fruit genotype, it was $2.58 \%$ at $50 \mathrm{~d}$ and $4.33 \%$ at $82 \mathrm{~d}$; and for the sweet passion fruit, it was estimated at $0.89 \%$ at $50 \mathrm{~d}$ and $1.22 \%$ citric acid at $81.99 \mathrm{~d}$ (Fig. 1).

A higher citric acid content in fruit juice is important because it allows greater flexibility in the addition of sugars for beverage preparations and reduces the deterioration processes caused by microorganisms (Flores et al., 2011). Although a higher acidity content leads to a longer shelf-life, fruits with this characteristic do not have the sweet taste that is highly desirable for fresh consumption (Rotili et al., 2018). However, for industrial uses, a high acidity content, usually between 2.9 and $5.0 \%$, is desirable (Silva et al., 2016a).

The vitamin $\mathrm{C}$ content presented a quadratic behavior during the evaluation days, which was higher at the beginning of the physiological development and lower at the highest maturity point for the different evaluated species (FB 200 cultivar, yellow passion fruit and sweet passion fruit). The yellow passion fruits had the highest vitamin $\mathrm{C}$ content at the end of the evaluated periods, while the sweet passion

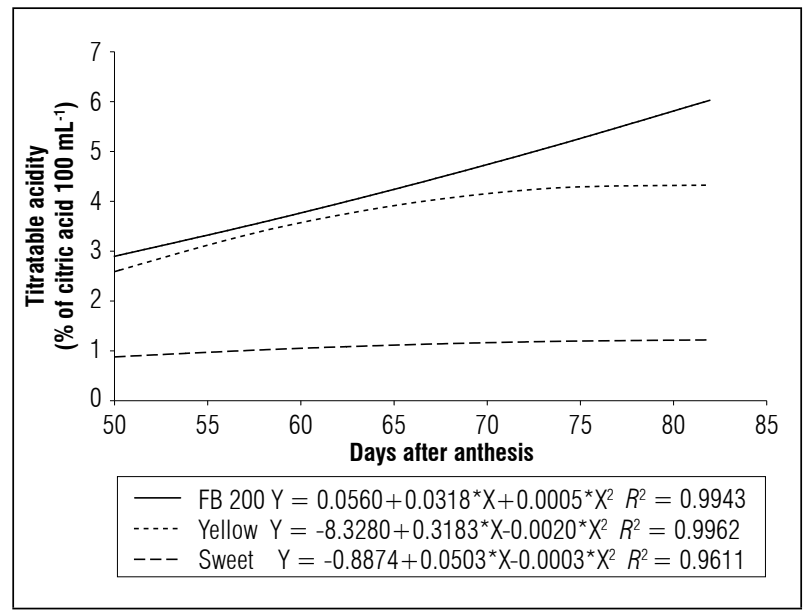

Figure 1. Titratable acidity of the pulp from different species: FB 200 cultivar (Passiflora edulis f. flavicarpa), yellow passion fruit (Passiflora edulis Sims) and sweet passion fruit (Passiflora alata) during the ripening. fruits presented the lowest content at 82 DAA. The ascorbic acid estimated for each $100 \mathrm{~mL}$ of pulp for the yellow passion fruit genotype was $79.86 \mathrm{mg}$ at $50 \mathrm{~d}$ and $62.43 \mathrm{mg}$ at $81.74 \mathrm{~d}$; for the FB 200 cultivar, it was estimated at $77.94 \mathrm{mg}$ at $50 \mathrm{~d}$ and $48.58 \mathrm{mg}$ at $82.09 \mathrm{~d}$. In the sweet passion fruit, it was estimated that the fruits had a vitamin C content of $66.15 \mathrm{mg}$ at $50 \mathrm{~d}$ and $31.54 \mathrm{mg}$ at $81.84 \mathrm{~d}$ (Fig. 2).

The decrease in the vitamin $\mathrm{C}$ content during ripening occurs because of the degradation caused by the ascorbate oxidase enzyme, which intensifies in activity when fruits mature (Costa et al., 2020). According to Coelho et al. (2010), the ascorbic acid content in fruit pulp is preserved throughout storage when fruits are harvested at an advanced ripening stage.

The carotenoid content in the yellow passion fruit and the FB 200 cultivar during ripening presented a quadratic behavior, and the content in the sweet passion fruits was adjusted to the linear model. There was an increase in carotenoids during the evaluated days, in which the commercial cultivar presented the highest content, and the sweet passion fruit presented the lowest carotenoid content, indicating that the cultivar has a predominance of pigments in its pulp, which is probably why its juice is yellower (Gomes et al., 2019). The carotenoid accumulation estimate during ripening for the FB 200 cultivar was $1.82 \mu \mathrm{g}$ $\mathrm{mL}^{-1}$ at $50 \mathrm{~d}$ and $2.88 \mu \mathrm{g} \mathrm{mL}^{-1}$ at $82.01 \mathrm{~d}$; for the yellow passion fruit, it was estimated at $1.08 \mu \mathrm{g} \mathrm{mL}^{-1}$ of

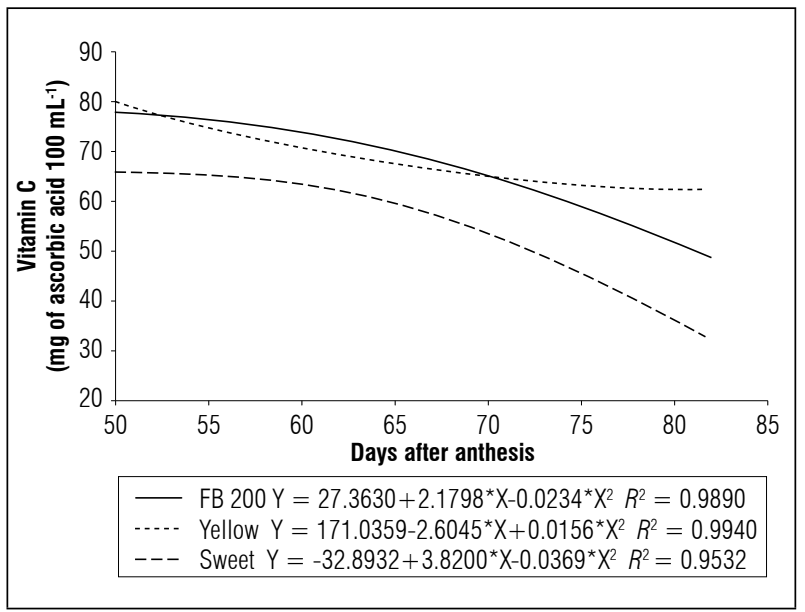

Figure 2. Vitamin $\mathbf{C}$ content in the pulp of different species: FB 200 cultivar (Passiflora edulis f. flavicarpa), yellow passion fruit (Passiflora edulis Sims) and sweet passion fruit (Passiflora alata) during ripening. 


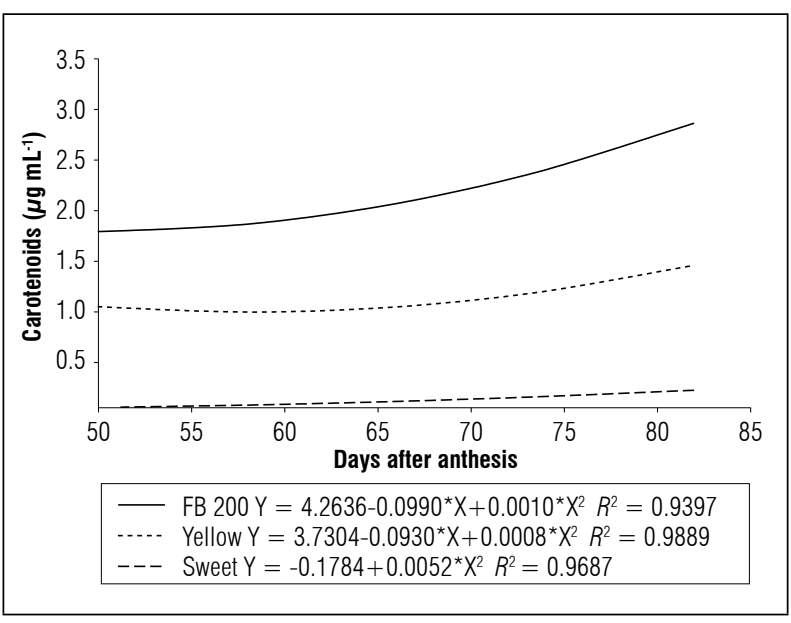

Figure 3. Total carotenoid content in the juice of different species: FB 200 cultivar (Passiflora edulis f. flavicarpa), yellow passion fruit (Passiflora edulis Sims) and sweet passion fruit (Passiflora alata) during ripening.

carotenoids at $50 \mathrm{~d}$ and $1.48 \mu \mathrm{g} \mathrm{mL}^{-1}$ at $81.74 \mathrm{~d}$. The carotenoid content estimated for the sweet passion fruit during ripening was $0.10 \mu \mathrm{g} \mathrm{mL}^{-1}$ at 51.22 and $0.27 \mu \mathrm{g} \mathrm{mL}^{-1}$ at $82.11 \mathrm{~d}$ (Fig. 3).

Carotenoids are important precursors of vitamin $\mathrm{A}$ and have considerable antioxidant activity that is associated with a reduced risk of degenerative diseases. They are responsible for intensifying the yellow coloration of the pulp. Levels vary according to the fruit ripening stage and are synthesized during maturation by metabolic pathways to act as antioxidants (Rotili et al., 2013).

The soluble solids content was adjusted to the quadratic model, increasing with ripening and reaching the highest level at 82 DAA. During the experiment, the sweet passion fruit presented the highest soluble solids content, which is one of its main characteristics, and the FB 200 cultivar presented a reduced soluble solids content, probably caused by the high titratable acidity content (Tab. 1) since a decrease in the soluble solids content leads to an increase in titratable acidity (Munaretto et al., 2020). The soluble solids content estimated during the ripening of the sweet passion fruits was $13.93^{\circ} \mathrm{Brix}$ at $55.47 \mathrm{~d}$ and $22.49^{\circ}$ Brix at $81.84 \mathrm{~d}$; for the yellow passion fruits, it was $14.52^{\circ}$ Brix at $50.04 \mathrm{~d}$ and $17.53^{\circ}$ Brix at $81.79 \mathrm{~d}$. For the FB 200 cultivar, the soluble solids content was estimated at $12.92^{\circ}$ Brix at $50.04 \mathrm{~d}$ and $16.05^{\circ}$ Brix at 82.04 d (Fig. 4).

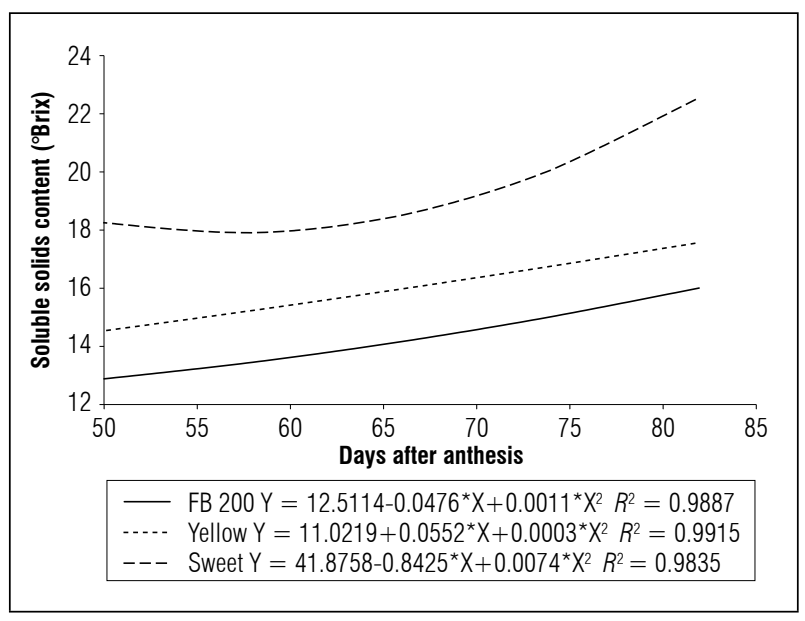

Figure 4. Soluble solids content in the fruit juice of different species: FB 200 cultivar (Passiflora edulis f. flavicarpa), yellow passion fruit (Passiflora edulis Sims) and sweet passion fruit (Passiflora alata) during ripening.

Soluble solids are water-soluble compounds that indicate the amount of sugars in fruit pulp, with other compounds at reduced proportions, such as acids, vitamins, amino acids, and some pectins. The highest point of soluble solid accumulation is reached at the end of maturation (Chitarra and Chitarra, 2005). Several factors affect the soluble solids content, especially weather conditions, harvest point, and harvest season (Moura et al., 2016). The industry prefers fruits with a soluble solids content of about $14^{\circ}$ Brix because it allows better technological productivity, which means a lower amount of sugar will be necessary for passion fruit juice production (Silva et al., 2018).

The evaluation of soluble solids content is one of the most efficient ways to assay fruit quality because it has compounds that give the fruit flavor, which makes them more desirable in the consumer market and in the processing industry. In addition, fruits with higher soluble solids contents mean that a smaller number of fruits is used in juice production (Dias et al., 2017).

The soluble solids content/titratable acidity (SSC/ TA) ratio presented a quadratic behavior, increasing during ripening and reaching the highest content at 82 DAA. The yellow passion fruit and FB 200 cultivar presented lower values for the ratio, and the sweet passion fruit presented the highest ratio. The estimated ratio for the sweet passion fruit was 15.86 at 
$57.59 \mathrm{~d}$ and 27.13 at $81.87 \mathrm{~d}$; for the yellow passion fruit, the ratio estimate was 3.52 at $53.08 \mathrm{~d}$ and 6.71 at $81.74 \mathrm{~d}$. The estimated ratio for the FB 200 cultivar was 2.60 at 50.02 and 4.91 at $82.01 \mathrm{~d}$ (Fig. 5).

The ratio had a balance between sugars and acidity content; therefore, sweeter fruits lead to higher SSC/

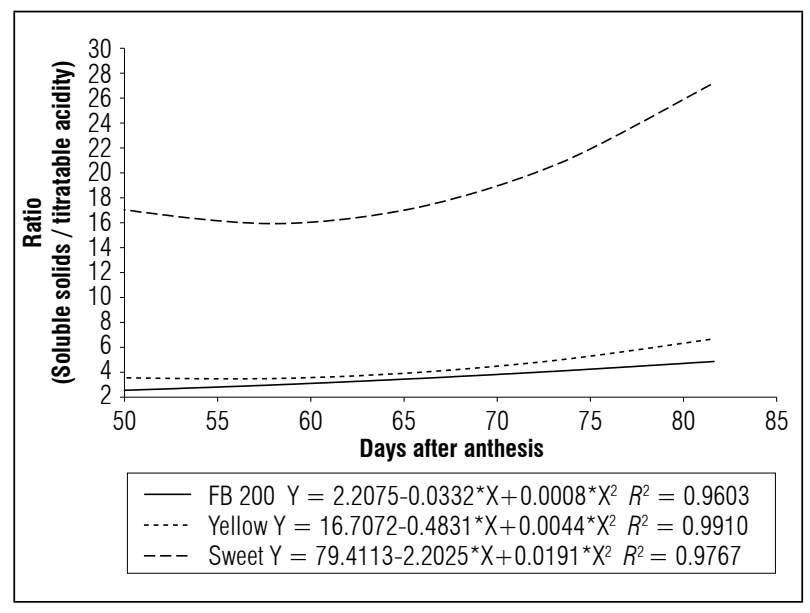

Figure 5. Soluble solids/titratable acidity ratio in the juice of different species: FB 200 cultivar (Passiflora edulis f. flavicarpa), yellow passion fruit (Passiflora edulis Sims) and sweet passion fruit (Passiflora alata) during ripening.

TA values (Silva et al., 2016b). The ratio is a very important characteristic because a balance between the soluble solids content and acidity determines the fruit flavor (Rotili et al., 2018).

At the end of the experiment (82 DAA), the epidermis of the yellow passion fruit and sweet passion fruit presented similar hue angle values $\left(h^{\circ}\right)$ without a significant difference. The FB 200 cultivar, however, differed statistically from the others, presenting a hue angle of $95.10^{\circ}$ (Tab. 1). These results indicate that the FB 200 cultivar presented fruits with a more intense epidermis color although all evaluated fruits were closer to the yellow color according to the $L^{*} C^{*} h^{\circ}$ (Ferreira and Spricigo, 2017).

Color is one of the main aspects used by consumers to evaluate fruit quality (Rotili et al., 2018). Salazar et al. (2015) obtained a hue angle closer to $90^{\circ}$ for yellow passion fruits, which, according to the authors, indicates a more intense yellow color, caused by the process of chlorophyll degradation in the pericarp and by the synthesis and/or manifestation of carotenoids. Similar hue angle values were obtained by ViannaSilva et al. (2010) for yellow passion fruits at 63 DAA.

The titratable acidity had a significant difference between the evaluated species. The FB 200 cultivar fruits had the highest acidity content, and the sweet passion fruits presented the lowest values (Tab. 1), probably because of its main characteristics, which include a sweet taste and low acidity (Alves et al., 2012). A minimum of $2.5 \%$ citric acid is demanded by the industry by default for passion fruit pulp used in juice processing (Viana et al., 2016).

The acidity content obtained in the present study for the FB 200 cultivar and yellow passion fruit corroborates the values obtained by Gomes et al. (2019), who obtained 4.56 and $5.34 \%$ citric acid, respectively, for these fruits under the conditions of the Brazilian Savanna. Ferreira and Antunes (2019) observed yellow passion fruits in São Paulo state - Brazil with about $4 \%$ citric acid. Botelho et al. (2017) evaluated fruits from the FB 200 cultivar in Mato Grosso state - Brazil and obtained pulp with about 3\% acidity. The acidity content in fruit pulp varies according to the ripening stage, where the ripest fruits present a lower acidity (Braga et al., 2020).

Table 1. Fruit characterization of passion fruit from different species: FB 200 cultivar (Passiflora edulis f. flavicarpa), yellow passion fruit (Passiflora edulis Sims) and sweet passion fruit (Passiflora alata) at 82 DAA.

\begin{tabular}{|l|c|c|c|c|c|c|}
\hline $\begin{array}{c}\text { Passion } \\
\text { fruit }\end{array}$ & $\begin{array}{c}\text { Hue angle } \\
\left(\mathrm{h}^{\circ}\right)\end{array}$ & $\begin{array}{c}\text { Titratable acidity } \\
(\% \text { of citric acid/100 mL) }\end{array}$ & $\begin{array}{c}\text { Vitamin C } \\
(\mathrm{mg} \text { of ascorbic acid/100 mL) }\end{array}$ & $\begin{array}{c}\text { Carotenoids } \\
\left(\mu \mathrm{g} \mathrm{mL}^{-1}\right)\end{array}$ & $\begin{array}{c}\text { Soluble solids content } \\
\left({ }^{\circ} \text { Brix }\right)\end{array}$ & $\begin{array}{c}\text { SSC/TA } \\
\text { ratio }\end{array}$ \\
\hline FB 200 & $95.10 \mathrm{a}$ & $4.19 \mathrm{a}$ & $66.21 \mathrm{a}$ & $2.12 \mathrm{a}$ & $14.13 \mathrm{c}$ & $3.58 \mathrm{~b}$ \\
\hline Yellow & $80.54 \mathrm{~b}$ & $3.59 \mathrm{~b}$ & $69.15 \mathrm{a}$ & $1.19 \mathrm{~b}$ & $15.83 \mathrm{~b}$ & $4.63 \mathrm{~b}$ \\
\hline Sweet & $80.75 \mathrm{~b}$ & $1.01 \mathrm{c}$ & $53.55 \mathrm{~b}$ & $0.17 \mathrm{c}$ & $19.41 \mathrm{a}$ & $19.72 \mathrm{a}$ \\
\hline CV (\%) & 18.63 & 12.52 & 13.25 & 23.25 & 16.67 & 15.65 \\
\hline
\end{tabular}

Means followed by the same letter are not different $(P<0.05)$ according to Tukey's test. 
The soluble solids content differed among the species. The sweet passion fruit produced fruits with the highest soluble solids content, confirming the sweet flavor attributed to this species. The FB 200 cultivar presented the lowest solids content (Tab. 1). Gama et al. (2013) produced fruits from the FB 200 cultivar with a soluble solids content of $13.1^{\circ}$ Brix. Braga et al. (2017) evaluated the chemical characteristics of yellow passion fruit and reported fruits with a soluble solids content of $13^{\circ}$ Brix. The values observed in the present study agree with the standard established by the Brazilian Ministry of Agriculture and Supplies for the quality standards of passion fruit, i.e. at least 11 ${ }^{\circ}$ Brix (Mapa, 2018).

The ratio between the titratable acidity and soluble solids content was higher in the sweet passion fruit, which differed from the values observed for the yellow passion fruit and FB 200 cultivar (Tab. 1). Fruit flavor is represented by the titratable acidity and soluble solids ratio, in which a lower acidity content implies a higher ratio (Braga et al., 2017). The SSC/ TA ratio tends to increase during ripening because of a reduction in acidity levels. The bigger the ratio is, the better the fruit quality will be, leading to more acceptance by consumers (Silva et al., 2019).

The SSC/TA ratio for yellow passion fruit, by default, ranges from 3.0 to 4.5 (Chitarra and Chitarra, 2005). Dias et al. (2017), who worked with different cultivars of the yellow passion fruit, obtained a ratio lower than 2, probably because the acidity content was higher than $8 \%$ in all evaluated cultivars. Borges et al. (2020) obtained an SSC/TA ratio for sweet passion fruit ranging from 8 to 17. Moura et al. (2020) evaluated fruits from the FB 200 cultivar and obtained an SSC/TA ratio of 3.0, similar to the results founded in the present study.

The vitamin C content in the FB 200 cultivar did not differ from the yellow passion fruit; however, both differed from the sweet passion fruit, which presented a lower vitamin $\mathrm{C}$ content (Tab. 1). The recommended daily intake according to the Brazilian Ministry of Health is $45 \mathrm{mg}$ of vitamin C for adults (Anvisa, 2003); values equal to or greater than this recommendation confer benefits to human health, reducing the risk of developing chronic diseases.

Despite being very important to nutrition, there is no requirement for the vitamin $\mathrm{C}$ content of fruits in the processing industry (Moura et al., 2016). The ripening stage and production location, along with other factors, influence the values of this content (Estevam et al., 2018). Salazar et al. (2015), who evaluated yellow passion fruits grafted on wild species of the Passiflora genus in a greenhouse, obtained a vitamin $\mathrm{C}$ content

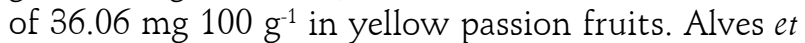
al. (2012) obtained approximately $20 \mathrm{mg} 100 \mathrm{~mL}^{-1}$ for sweet passion fruits produced in Viçosa-MG, Brazil. Conde et al. (2017) obtained about $25 \mathrm{mg}$ of ascorbic acid in purple passion fruits produced in Colombia.

For the carotenoid content, the species differed from each other, with the FB 200 cultivar presenting the highest levels (Tab. 1). According to Zeraik et al. (2010), high levels of carotenoids are responsible for promoting a more intense juice color, and the synthesis of carotenoids is influenced by the season in which fruits are produced.

\section{CONCLUSION}

The post-harvest properties of fruits of different passion fruit species vary during ripening, which sees an adjustment of the characteristics responsible for good acceptance in the consumer market. At 82 DAA, the fruits of the yellow passion fruit and cultivar FB 200 presented desirable characteristics for industrial use and fresh consumption. During ripening, the sweet passion fruit presented a higher SSC/TA ratio because of its high content of soluble solids and low acidity content, resulting in a better fruit flavor.

\section{Acknowledgments}

The authors are grateful to Conselho Nacional de Desenvolvimento Científico e Tecnológico (CNPq) and Coordenação de Aperfeiçoamento de Pessoal de Nível Superior (CAPES) for their financial support.

Conflict of interests: The manuscript was prepared and reviewed with the participation of the authors, who declare that there exists no conflict of interest that puts at risk the validity of the presented results.

\section{BIBLIOGRAPHIC REFERENCES}

Aires, E.S., C.A. Aragão, I.L.S. Gomes, G.N. Souza, and I.G.V. Andrade. 2020. Alternative substrates for production of yellow passion fruit seedlings. Rev. Agric. Neotrop. 7(1), 43-48. Doi: 10.32404/rean.v7i1.3890

Alves, R.R., L.C.C. Salomão, D.L. Siqueira, P.R. Cecon, and D.F.P. Silva. 2012. Relações entre características físicas e químicas de frutos de maracujazeiro-doce cultivado em Viçosa-MG. Rev. Bras. Frutic. 34(2), 619-623. Doi: 10.1590/S0100-29452012000200038 
Anvisa, Agência Nacional de Vigilância Sanitária of Brazil. 2003. Regulamento técnico sobre rotulagem nutricional de alimentos embalados. http://portal.anvisa.gov. br/documents/33880/2568070/res0360_23_12_2003. $\mathrm{pdf} / 5 \mathrm{~d} 4 \mathrm{fc} 713-9 \mathrm{c} 66-4512-\mathrm{b3c1-afee} 57 \mathrm{e} 7 \mathrm{~d} 9 \mathrm{bc} ;$ consulted: August, 2020.

$\mathrm{AOAC}$, Association of Official Analytical Chemists International. 2016. Official methods of analysis of the Association of Official Analytical Chemists International. 20 th ed. Washington, DC. pp. 945- 989.

Arruda, M.D., I.H. Fischer, M. Zanette, B. Silva, and C. Santos. 2011. Qualidade físico química de frutos de laranja Valência provenientes de cultivos orgânico e convencional. Citrus Res. Technol. 32(2), 103-108. Doi: 10.5935/2236-3122.20110012

Benevides, S.D., A.M. Ramos, P.C. Stringheta, and V.C. Castro, 2008. Qualidade da manga e polpa da manga Ubá. Ciênc. Tecnol. Aliment. 28(3), 571-578. Doi: 10.1590/S0101-20612008000300011

Borges, R.M., E.R. Alencar, A.M. Costa, and N.T.V. Junqueira. 2020. Physicochemical aspects of genotypes of Passiflora alata Curtis. Braz. J. Food Technol. 23, e2019188. Doi: 10.1590/1981-6723.18819

Botelho, S.C.C., M.R. Hauth, F.M. Botelho, G. Roncatto, C. Wobeto, and S.S. Oliveira. 2019. Qualidade pós-colheita de frutos de maracujazeiro-amarelo colhidos em diferentes estádios de maturação. Rev. Ciênc. Agrar. 62, 1-8. Doi: 10.22491/rca.2019.3005

Botelho, S.C.C., G. Roncatto, F.M. Botelho, S.S. Oliveira, and C. Wobeto. 2017. Qualidade pós-colheita de frutos de maracujazeiro-amarelo produzidos em mato grosso. Nativa 5(Spec.), 471-476. Doi: 10.5935/23187670.v05nespa02

Braga, L.A.C., F.B. Penha, L.F.A. Souza, A.C.C. Braga, E.C.N. Rodrigues, T.S. Bezerra, and P.D. Oliveira. 2020. Perfil sensorial e avaliação físico-química de néctar misto de Pitaya e Maracujá. Braz. J. Develop. 6(6), 3897038987. Doi: 10.34117/bjdv6n6-440

Braga, C.S., D.V. Rodrigues, R.B. Bispo, V. Götter, K.C. Martins, and S.A.M. Souza. 2017. Caracterização e diversidade genética de espécies do gênero Passiflora com base em características físicas e químicas dos frutos. Rev. Ciênc. Agroamb. 15(2), 181-186. Doi: 10.5327/ Z1677-606220172002

Chitarra, M.I.F. and A.B. Chitarra. 2005. Pós-colheita de frutas e hortaliças: fisiologia e manuseio. $2^{\text {nd }} \mathrm{ed}$. UFLA, Lavras, Brazil.

Coelho, E.M., L.C. Azevêdo, and M.A. Umza-Guez, 2016. Fruto do maracujá: importância econômica e industrial, produção, subprodutos e prospecção tecnológica. Cadern. Prospec. 9(3), 347. Doi: 10.9771/cp.v9i3.16637

Coelho, A.A., S.A. Cenci, and E.D. Resende. 2010. Qualidade do suco de maracujá-amarelo em diferentes pontos de colheita e após o amadurecimento. Ciênc. Agrotec. 34(3), 722-729. Doi: 10.1590/ S1413-70542010000300027
Conde, C.G., K.P.T. Guardo, E.G. Llamas, N.P. Pájaro-Castro, and Y.G. Milano. 2017. Caracterización química y evaluación de la actividad antioxidante de la pulpa de Passiflora edulis Sims (gulupa). Rev. Cuba Plant. Med. $22(2)$.

Costa, M.S., F.A.C. Almeida, B.E.S. Coelho, J.D.S. Costa, and A. Figueiredo Neto. 2020. Composição química da polpa de manga 'Ataulfo' em diferentes estádios de maturação. J. Environ. Analys. Prog. 5(1), 11-16. Doi: 10.24221/jeap.5.1.2020.2637.011-016

Dias, D.G., R.F. Pegoraro, V.M. Maia, and A.C. Medeiros. 2017. Production and postharvest quality of irrigated passion fruit after N-K fertilization. Rev. Bras. Frutic. 39(3), e-553. Doi: 10.1590/0100-29452017553

Estevam, M.I.F., P.A. Souza, P.B. Maracajá, E.M. Batista, and B.M. Reges. 2018. Físico-química de variedades de acerola em dois estádios de maturação. Rev. Verde Agroeco. Des. Sus. 13(4), 459-465. Doi: 10.18378/ rvads.v13i4.5736

Ferreira, M.O. and M.A. Antunes. 2019. Qualidade de frutos de maracuja amarelo comercializados na CEAGESP - Bauru - SP. Rev. Agrofib. 1(1), 71-84.

Ferreira, M.D. and P.C. Spricigo. 2017. Colorimetria - princípios e aplicações na agricultura. pp. 209-220. In: Ferreira, M.D. (ed). Instrumentação pós-colheita em frutas e hortaliças. Embrapa Instrumentação, São Carlos, Brazil.

Flores, P.S., D.F.P. Silva, C.H. Bruckner, S.P. Oliveira, and L.C.C. Salomão. 2011. Caracterização físico-química de frutos de maracujazeiro amarelo provenientes da irradiação com raios gama. Ciênc. Rural 41(11), 19031906. Doi: 10.1590/S0103-84782011001100009

Gama, V.N., J.T. Cunha, I.M. Lima, M.A. Bacarin, and D.M. Silva. 2013. Photosynthetic characteristics and quality of five passion fruit varieties under field conditions. Acta Physiol. Plant. 35(3), 941-948. Doi: 10.1007/ s11738-012-1137-1

Gomes, F.R., P.H.M. Souza, M.M. Costa, D.G. Sena-Júnior, A.L.P. Souza, V.M. Azevedo, L.C. Carneiro, S.C.S. Cruz, and D.F.P. Silva. 2019. Quality of the pulp of passion fruit produced in the Brazilian Savanna. J. Agric. Sci. 11(4), 470-475. Doi: 10.5539/jas.v11n4p470

Hurtado-Salazar, A., D.F.P. Silva, N. Ceballos-Aguirre, J. Ocampo, and C.H. Bruckner. 2020. Promissory passiflora species (Passifloraceae) for its tolerance to water-salt stress. Rev. Colomb. Cienc. Hortic. 14(1), 44-49. Doi: 10.17584/rcch.2020v14i1.10574

Kong, X., M.J. Murdoch, I. Vogels, D. Sekulovski, and I. Heynderickx. 2019. Perceived speed of changing color in chroma and hue directions in CIELAB. J. Opt. Soc. Am. 36(6), 1022-1032. Doi: 10.1364/JOSAA.36.001022

Lichtenthaler, H.K. 1987. Chlorophylls and carotenoids: pigment photosynthetic biomembranes. Method. Enzymol. 148, 362-385. Doi: 10.1016/0076-6879(87)48036-1

Mapa, Ministério da Agricultura, Pecuária e do Abastecimento of Brazil. 2018. Regulamento técnico para 
fixação dos padrões de identidade e qualidade para suco de maracujá. In: http://pesquisa.in.gov.br/imprensa/jsp/visualiza/index.jsp?data $=08 / 10 / 2018 \&-$ jornal $=515 \&$ pagina $=26 \&$ totalArquivos $=232$; consulted: August, 2020.

Martínez, M.A., A.C. Morillo, and W. Reyes-Ardila. 2020. Characterization of the genetic diversity in Passiflora spp. in the Boyacá department, Colombia. Chil. J. Agri. Res. 80(3), 342-351. Doi: 10.4067/ S0718-58392020000300342

Medeiros, S.A.S., M.A.F. Bezerra, J.A.M. Nascimento, L.F. Cavalcante, C.A.S. Freitas, and C.S. Ferreira. 2020. Yield and postharvest quality of yellow passion fruit under water irrigation depths, phosphate and organic fertilization. Irriga 25(1), 14-26. Doi: 10.15809/ irriga.2020v25n1p14-26

Melo, B.M., and D.P. Dias. 2019. Microclima e conforto térmico de remanescentes florestais urbanos no município de Jataí-GO. Rev. Soc. Bras. Arbor. Urb. 14(2), 1-15. Doi: 10.5380/revsbau.v14i2.66637

Moura, M.M., J.C.M. Rufini, M.C.P. Fagundes, A.C.P. Pereira, M.A.P. Barbosa, and G.S. Alves. 2020. Flowering, fruit production and quality of passion fruit hybrids in Minas Gerais, Brazil. Com. Sci. 11, e3478.

Moura, G.S., K.R.F. Schwan-Estrada, E. Clemente, and G. Franzener. 2016. Conservação pós-colheita de frutos de maracujá-amarelo por derivados de capim-limão (Cymbopogon citratus). Amb. Guar. 12(2), 667-682. Doi: 10.5935/ambiencia.2016.02.11

Munaretto, L.M., T. Silva, R.V. Botelho, and J.T.V. Resende. 2020. Quality of black berries cv. Xavante treated in pre-harvest with silicon. Ap. Res. Agrotechn. 13, 6495-1.

Nascimento, K.C. and J.F. Barbosa. 2014. Caracterização morfoanatômica de nectários extraflorais de Passiflora alata, Passifloraceae. Rev. Uningá Rev. 20(1), 45-50.

Pereira, L.D., K.D. Valle, L.K.F. Souza, E.F. Paiva, C.C. Bolina, E.F. Reis, A.H. Salazar, and D.F.P. Silva. 2018. Caracterização de frutos de diferentes espécies de maracujazeiro. Rev. Bras. Agropec. Susten. 8(2), 21-28. Doi: $10.21206 /$ rbas.v8i2.502

Ribeiro, R.M., A.P. Viana, E.A. Santos, D.L. Rodrigues, and S.C. Preisigke. 2019. Breeding passion fruit populations - review and perspectives. Funct. Plant Breed. J. 1(1), art.2. Doi: 10.35418/2526-4117/v1n1a2

Rotili, M.C.C., S. Coutro, V.M. Celant, J.A. Vorpagel, F.K. Barp, A.B. Salibe, and G.C. Braga. 2013. Composição, atividade antioxidante e qualidade do maracujá-amarelo durante armazenamento. Semina: Ciênc. Agr. 34(1), 227-240. Doi: 10.1590/S0100-29452013000400004

Rotili, M.C.C., F. Villa, G.C. Braga, D.L.B. França, S. Rosanelli, J.C.U. Laureth, and D.F. Silva. 2018. Bioactive compounds, antioxidant and physic-chemical characteristics of the dovyalis fruit. Acta Sci. Agron. 40(1), e35465. Doi: 10.4025/actasciagron.v40i1.35465

Salazar, A.H., D.F.P.D. Silva, C.S. Sediyama, and C.H. Bruckner. 2015. Caracterização física e química de frutos de maracujazeiro-amarelo enxertado em espécies silvestres do gênero Passiflora cultivado em ambiente protegido. Rev. Bras. Frutic. 37(3), 635-643. Doi: 10.1590/0100-2945-101/14

SAS, Statistical Analysis System. 2004. SAS/STAT user guide, Version 9.1. 2. Cary, NC.

Silva, M.S., E.M. Ataíde, A.K.E. Santos, and J.M.A. Souza. 2016a. Qualidade de frutos de maracujazeiro amarelo produzidos na safra e entressafra no Vale do São Francisco. Rev. Iber. Tecn. Postc. 17(1), 41-49.

Silva, Q.J., F.J. Figueiredo, and V.L.A.G. Lima. 2016b. Características físicas e químicas de cirigueleiras cultivadas na Zona da Mata Norte de Pernambuco. Rev. Ceres 63(3), 285-290. Doi: 10.1590/0034-737X201663030002

Silva, T.V., E.D. Resende, A.P. Viana, R.C.C. Rosa, S.M.F. Pereira, L.A. Carlos, and L. Vitorazi. 2005. Influência dos estádios de maturação na qualidade do suco do maracujá-amarelo. Rev. Bras. Frutic. 27(3), 472-475. Doi: 10.1590/S0100-29452005000300031

Silva, A.C.G., N.S. Silva, and F.F. Souza. 2019. Pós-colheita do maracujá amarelo com revestimentos a base de amido da entrecasca de mandioca. Rev. Verde 14(2), 238-245. Doi: 10.18378/rvads.v14i2.6220

Silva, L., M.S. Silveira, R.A. Pereira, and M.A. Bezerra. 2018. Composição físico-química e bioativa dos frutos de Passiflora tenuifila Killip (maracujá-alho). Rev. Cuba. Plant Med. 24(1).

Viana, M.L., A.M. Costa, and S. Celestino. 2016. Informações para a composição de tabela nutricional da polpa do maracujá BRS Pérola do Cerrado. Bol. Pesqui. Desenvolv. 335. Embrapa Cerrados, Planaltina, Brazil.

Vianna-Silva, T., R.V. Lima, I.G. Azevedo, R.C.C. Rosa, M.S. Souza, and J.G. Oliveira. 2010. Determinação da maturidade fisiológica de frutos de maracujazeiro amarelo colhidos na região norte do estado do Rio de Janeiro, Brasil. Rev. Bras. Frutic. 32(1), 57-66. Doi: 10.1590/S0100-29452010005000012

Vianna-Silva, T., E.D.D. Resende, A.P. Viana, S.M.D.F. Pereira, L.D.A. Carlos, and L. Vitorazi. 2008. Qualidade do suco de maracujá-amarelo em diferentes épocas de colheita. Food Sci. Tech. 28(3), 545-550. Doi: 10.1590/ S0101-20612008000300007

Zeraik, M.L., C.A.M. Pereira, V.G. Zuin, and J.H. Yariwake. 2010. Maracujá: um alimento funcional? Rev. Bras. Farmac. 20(3), 459-471. Doi: 10.1590/ S0102-695X2010000300026 